\title{
Kaşgarlı şair Turdî Nâzım Garîbî’nin Kitâb-ı Garîbî adlı eseri
}

Esra GÜNEŞ ASÍL ${ }^{1}$

Sibel MURAD 2 APA: Güneş Asil, E.; Murad, S. (2020). Kaşgarlı şair Turdî Nâzım Garîbî’nin Kitâb-ı Garîbî adlı eseri.
RumeliDE Dil ve Edebiyat Araştırmaları Dergisi, (19), 494-503. DOI: 10.2900o/rumelide.752441.

\section{$\ddot{\mathbf{O} z}$}

Bu çalışmada “Kitāb-ı Garîbı̂” olarak da bilinen, asıl adı “Ottuz Ėkki Eṣnāfnı̀ Birbiri İle Gep Talaşḳanı” olan eser tanıtılacaktır. Eser şiirlerinde Garîbî mahlasını kullanan, tarihî kaynaklarda kendisinden Turdî Nâzım ve Turduş Ahun olarak da bahsedilen 19.yy Uygur Divan Edebiyatı temsilcilerinden Kaşgarlı Garîbî̀ye aittir. H. 1257 (M. 1841-1842) yılında Arap harfleriyle kaleme alınan eser H. 1320'de (M. 1902-1903) Bulgaristan'ın Şumnu şehrinde, Johannes Avetaranian Basımevi'nde basılmıştır. 145 sayfalık eser, mukaddime, mesleklerin tanıtımı, esnafların atışma bölümleri, sebeb-i telif ve basımevi sahibinin notlarının olduğu bölüm ile birlikte toplam 37 bölümden meydana gelmektedir. Eserin bölüm girişlerinde, açıklama niteliğinde 5-6 satırlık nesirler yer almaktadır. Bölüm girişleri dışında eserin geneli manzumdur. "Kitāb-ı Garîbı̂” içerik olarak Uygur Edebiyatının yazılı kültür ürünlerinden olan meslek risalelerine benzemekle birlikte mesleklerin tanıtımlarını ve bunların gerektirdiği ahlak kurallarını atışma geleneği içinde manzum olarak işlemesi yönüyle meslek risalelerinden ayrılmaktadır. Eserde demircilik, bakırcılık, fırıncılık, çiftçilik, çömlekçilik, dokumacılık, ayakkabıcılık, marangozluk gibi farklı meslek kolları hakkında önemli bilgiler yer almaktadır. "Kitāb-ı Garîbî”de meslek kollarının tanıtımının yanında esnafların atıştıkları ve sorucevap şeklinde söyleştikleri bölümler de bulunmaktadır. 19. yy'da kaleme alınan eser, dili bakımından Çağatay Türkçesinin son dönemine dâhil edilebilir. Bu çalışmada tarafımızdan yüksek lisans tezi olarak hazırlanmakta olan "Kitāb-ı Garîbı̂” tanıtılarak eserin muhtevası ve bazı dil özellikleri hakkında bilgi verilmiştir.

Anahtar kelimeler: Çağatay Türkçesi, Yeni Uygur Türkçesi, Kaşgarlı Turdî Nâzım, Kitâb-ı Garîbî

\section{The work of poet Turdî Nâzım Garîbî's Kitâb-ı Garîbî}

\begin{abstract}
This study aims to introduce the work known as "Kitāb-1 Garîbî", authentic name of which is "Ottuz Ėkki Eșnāfnın Birbiri İle Gep Talaşḳanı”. The work belongs to Garîbî of Kashgar, who used the pseudonym Garîbî in his poems, and one of the representatives of the 19th century Uyghur Divan Literature. Garîbî of Kashgar is also mentioned in historical sources as Turdî Nâzım and Turduş Ahun. The book, written in Arabic letters in Hijri 1257 (1841-1842), was published in Johannes Avetaranian Printing House in Shumen, Bulgaria in Hijri 1320 (1902-1903). The 145-page work consists of a total of 37 sections, together with the preliminary, the introduction of the professions, the quarrel (call and response duet) sections of the craftsmen, the reason for the copyright and the
\end{abstract}

\footnotetext{
$1 \quad$ YL Öğrencisi, Amasya Üniversitesi, Sosyal Bilimler Enstitüsü, Türk Dili ve Edebiyatı ABD (Amasya, Türkiye), esraagns@gmail.com, ORCID ID: 000o-0002-0053-3611] [Makale kaylt tarihi: 23.04.2020-kabul tarihi: 20.06.2020; DOI: $10.29000 /$ rumelide.752441]

2 Doç. Dr., Amasya Üniversitesi, Fen Edebiyat Fakültesi, Türk Dili ve Edebiyatı Bölümü (Amasya, Türkiye), sibel.murad@amasya.edu.tr, ORCID ID: 0000-0003-0175-7702.
} 
printing house owner's notes. In the section entries of the work, there are 5-6 lines of prose sentences. Apart from the entries of these sections, the overall work is poetical. Although content of "Kitāb-1 Garîbî" is similar to the occupational pamphlets, which is one of the written cultural products of Uyghur Literature, it differs from them in terms of introducing the professions and the moral rules required by them in the tradition of quarrelling (call and response duet). The work contains important information about different professions such as blacksmithing, copper making, bakery, farming, pottery, weaving, shoemaking, carpentry. In "Kitāb-ı Garîbî”, there are also sections where craftsmen quarrel (call and response duet) and have conversation in the form of questions and answers, in addition to the promotion of their professions. The work written in the 19th century can be included in the last period of Chagatai Turkish in terms of its language. In this study, "Kitāb-ı Garîbî" which is being prepared as a master thesis will be introduced and information about the content and certain language features of the work will be presented.

Keywords: Chagatai Turkish, Modern Uyghur Turkish, Kaşgarlı Turdî Nâzım, Kitâb-ı Garîbî

\section{Giriş}

Atışma, Türklerde çok eski zamanlardan beri süregelen saz ve söz aracılığıyla yapılan sözlü edebiyat geleneklerinden biridir. Bu gelenek, sözlü edebiyatın hem taşıyıcısı hem de kültürel mirasçısı olmuştur. Atışmalar, sözlü edebiyatın ürünü olduğu kadar yazılı edebiyatın da ürünüdür. 19.yy Uygur Divan Edebiyatı şairlerinden Kaşgarlı Turdî Nâzım’ın “Ottuz Ėkki Eșnāfnıı Birbiri İle Gep Talaşḳanı” veya bilinen adıyla "Kitâb-ı Garîbî” de bu geleneğe örnek teşkil eden eserlerden biridir.

Anadolu'da olduğu gibi Uygur edebiyatında da fütüvvet geleneği sözlü ve yazılı edebiyata konu olmuştur. $\mathrm{Bu}$ anlamda Uygur edebiyatında fütüvvet geleneğini yansıtan risalecilik geleneği gelişmiştir. Fütüvvet risaleleri, mesleklerin/iş kollarının iş tanımlarını yapmak yanında daha çok meslek sahiplerinin ve meslek adaylarının dinî bilgilerinin ve ahlakî değerlerinin gelişmesi için öğütler veren yazılı edebiyat ürünleridir. Bu gelenek ilk olarak sözlü edebiyatla başlamıştır. 18-19. yüzylllarda ise yazll hale getirildiği, yazı dili olarak da Çağatay Türkçesinin tercih edildiği bilinmektedir (Gönel Sönmez, 2017: 161). Sözü edilen risalelerde daha çok dihkānçılık (çiftçilik), mūze-dūzluk (çizmeci, ayakkabıcı), tegürmençilik (değirmenci) gibi yaygın meslekler tek tek ele alıp işlenir. "Kitâb-ı Garîbî" de bu risalelere meslekleri tanıtması yönünden benzese de birden çok mesleği ele alması ve esnafların atıştıkları bölümlere yer vermesi yönüyle diğer risalelerden farklıdır.

\section{Kaşgarlı Turdî Nâzım Garîbî}

Yeni Uygur Divan Edebiyatının (19. yy.) temsilcilerinden olan Turdî Nâzım, eserlerinde "Garîbî" mahlasını kullanmıştır. Bunu, Kitâb-ı Garîbînnin 139 nolu sayfasındaki 901. beyitte “Cihān içre gururbetde hālim ta'ab / Édi Turdi ismim $\dot{G} a r i \bar{b} \bar{i}$ lakab” ifadelerinden de anlamak mümkündür. Şair hakkında kaynaklarda ayrıntılı bilgi bulunmamakla beraber, "Çağdaş Uygur Türkleri’nin Edebiyatı" adlı eserde Durduş Ahun (Kaşgarlı, 1998, s. 43), "Türk Edebiyatı İsimler Sözlüğü” sitesinde Turdi Nâzım ve Turduş Ahun (http://www.turkedebiyatiisimlersozlugu.com), "Çağdaş Türk Edebiyatları-II" adlı kitabın 6. bölümünde de Turdi Geribiy olarak geçmektedir (Kasapolğlu Çengel vd., 2013, Ünite: 6).

Şair Turdî hakkında “Türk Edebiyatı İsimler Sözlüğü” en geniş bilgileri veren kaynaktır. Buradan edinilen bilgilere göre Turdî Nâzım Garîbî, H. 1217'de (M. 1802-1803) Kaşgar’ın Konaşeher ilçesine bağlı Karakaşlik Köyü’nde dünyaya gelmiştir. Zanaatkâr bir aileye sahip olan şair, ilk eğitimini Uygur divan 
şairlerinden Abdurrehim Nizârî̉’'den (1770-1850) almıştır. Şair, dinî ve edebî eğitimini Nizârî vasıtasıyla Kaşgar'da bulunan dönemin ünlü medresesi Hanlık Medresesi’nde tamamlamış, aynı zamanda Arapça ve Farsçayı da burada öğrenmiştir. Turdî’nin halk arasında tanınan eserleri Kitâb-ı Garîbî ile Behrâm ve Dilârâm'dır. Şaire ait eserlerin el yazmaları henüz bulunamamıştır. Hayatı hakkında kısıtlı bilgilere ulaşabildiğimiz Turdî, $\quad$ H. 1278-1279'da (M. 1862) Kaşgar'da vefat etmiştir (http://www.turkedebiyatiisimlersozlugu.com).

\section{Kitâb-ı Garîbî}

19. yy. Uygur divan edebiyatının temsilcilerinden olan Turdî Nâzım Garîbî̀ye ait "Divân-ı Garîbî" (Kaşgarlı, 1998: 43) olarak da bilinen Kitâb-ı Garîbî adlı eserin telif tarihi H. 1257’dir (M. 1841-1842). Telif tarihi, eserin yüz kırkıncı sayfası, sekizinci beytinde " Garīb ile mehni ḥesāb eylegil / Ki min ikki yüz ellik daǵ yètte yıl" ifadesiyle belirtilmiştir. Adem Öger, "Türk Edebiyatı İsimler Sözlüğü”nde yazdığı "Turdî Nâzım Garîbî" maddesinde, eserin yazma nüshasının olduğunu ancak henüz bulunamadığını, eserin halk arasında yayıldığını ifade eder (http://www.turkedebiyatiisimlersozlugu.com).

Elimizdeki Kitâb-ı Garîbî, Bulgaristan’ın Şumnu şehrinde, Johannes Avetaranian’ın “Avetaranian Matbaası”nda H.1320 (M. 1902-1903) tarihinde basılmıştır. Bu bilgi eserin 142. sayfasının son iki satırında şu şekilde yer almaktadır: “Bulğaristān'nıı Şumnı șehride Yoḥānnes Āvìdārānyān'nın basmahāneside basıldı tārīh̆ka hicretnin 1320'sıda.”. Eserin çalışmamızda kullandığımız bu matbu nüshası, Prof. Dr. Mehmet Fatih KÖKSAL’ın şahsi kütüphanesinde bulunmaktadır. ${ }^{4}$

Toplamda yüz kırk beş sayfa olan "Kitâb-ı Garîbı̂”, mukaddime ve mesleklerin tanıltıldı̆̆ı, esnafların mesleklerinin üstünlüklerini atışarak anlattıkları ve soru-cevap yoluyla dinî konularda söyleştikleri otuz altı bölümden oluşmaktadır. Eserin manzum kısımları 924 beyitten oluşmaktadır. Beyitler aruzun "feûlün/feûlün/feûlün/feûl" kalıbı ile yazılmıştır. Eserin manzum olarak yazılan bölümlerinden önce, bu bölümlerin içeriği hakkında bilgi veren kısa cümlelere yer verilmiştir. Mensur olan bu kısımlar, beşaltı satırı geçmeyen kısa cümlelerden oluşmaktadır. Bu cümleler, bölümler arası geçişleri sağlamaktadır. Eserin ilk 141 sayfası numaralandırılmış olup kalan dört sayfa ise numarasızdır.

Eserin mukaddime bölümü كنتكنزأَخفيًاً hadisi ile başlar. Mukaddime bölümü de diğer bölümler gibi mensur başlayıp manzum olarak devam eder. Bu bölümde, hadiste de söylendiği gibi Allah'ın bilinmek istediği, dünyayı yaratıp bezediği, insanı, hünerlerini ve otuz iki mesleği yarattığı, bu meslekleri insanlara bahşettiği anlatılmaktadır. Mukaddime bölümü, beş satırlık giriş cümlesinden sonra kırk beş beyitle devam etmektedir. Mukaddime bölümü sekizinci sayfanın beşinci satırında son bulur.

Mukaddime bölümünden sonra meslek kollarının ayrı ayrı tanıtıldı̆̆ı ve esnafların atıştıkları manzum bölümler başlamaktadır. Mukaddime bölümündeki gibi bu bölümlerden önce de kısa cümlelere yer verilmiştir. Bu bölümler sekizinci sayfanın altıncı satırıdır. Esnaflar mesleklerini tanıtırlarken diğer esnaflardan üstün yönlerini de dile getirerek atışmaları başlatırlar. İlk olarak çiftçilik (dihkânçılık) mesleği tanıtılır. Ardından demircilik (âhen-ger), kuyumculuk (zer-ger), marangozluk (neccâr), aktarlık (attâr), firıncılık (nân-vây), kazancılık (ḳazançı), bakırcılık (mis-ker), silahçılık (cebeçi), damcılık (tamçı), çizmecilik (mûze-dûz), kilimcilik (zîluçeçi), ustalık (üşte-ger/üstükar), boyacılık (boyakçı/sirçi), koşumculuk (serrāc), kumaşçı/basmacılık (basmaçı), değirmencilik (tẻgürmençi), hububatçılık (cev-bāzçı) kasaplık

3 Abdurrehim Nizârî hakkında ayrıntılı bilgi için bk. Öger ve Yılmaz, 2011.

4 Prof. Dr. Mehmet Fatih KÖKSAL hocamıza, kütüphanesindeki bu eseri çalışmamıza fırsat verdiği için teşekkürlerimizi borç biliriz.

5 Küntü kenzen mahfiyye : "Ben gizli bir hazineydim bilinmek istedim.”(Hadis-i kudsi) 
(ḳasap), bakkallık (baḳkāl), iplikçilik (ibrişīm-kār), dericilik (țabakçç/kimsendçi), nakkaşlık (naḳkāş), şalcılık (şal-ger), hasırcllık (buryāçı), keçecilik (nemedmān), sabunculuk (șābūnçı), kuşakçllı (ḳurçı/ḳurbāb), berberlik (ser-terāş), hallaçlık (atḳuçı), dericilik (könçi), kerpiççilik (hasşetçi) mesleklerinin tanıtımları esnafların kendi ağızlarından yapılır. Atışmaların yer aldığı bölümlerde mesleklerin tanıtılmalarının yanında meslek erbaplarının uyması gereken ahlakî değerlere ve birtakım ögütlere de yer verilmektedir. Mesleklerin tanıtıldı̆̆ı ve esnafların atıştıkları bu bölümler yetmiş beşinci sayfada son bulmaktadır.

Yetmiş altıncı sayfada meslek gruplarının yine esnaf olan ancak esnaflar içinde pîr ve rehber saydıkları kerpiç ustasına (haş̧etçiye) soru sorup kerpiç ustasının (haş̧eţimin) soruları cevapladı̆̆ bölümler başlamaktadır. Eserin başlığında yer alan "otuz iki esnaf” ibaresiyle de belirtilen otuz iki meslek erbabı bu bölümde kerpiç ustasına (haşetçiye) çeşitli sorular sorarlar. Bu sorular daha çok günah-sevaplar, meslek ahlakı, ölüm korkusu, kabir azabı, dünyanın yaratılışı, ibadet usulleri gibi konularla ilgilidir. Kerpiç ustası (haş̧etçi) ise bu sorulara verdiği cevaplarla esnafları doğruluğa, dürüstlüğe, dinî vecibeleri yerine getirmeye sevk eder. Erbapların namaz kılmanın önemiyle ilgili sordukları soruya kerpiç ustası, ömrü boyunca namaz kılmamış olanın Allah’tan bir şey isteyemeyeceğini anlatan “Eger ‘ömr içide namāz eylemey / Kirip mescid içre niyāz eylemey” beyitiyle cevap verir. Ölüm korkusu ile ilgili sorulan soruyu ise dünyaya bağlı ve hırslı olmanın insana zarar vereceğini, bunun da kişinin rahatça can vermesini

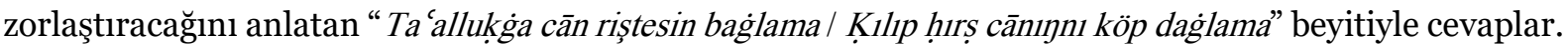
Soru-cevaptan oluşan bu bölüm 136. sayfaya kadar devam eder.

Yüz otuz altıncı sayfada şeriatın yol gösterici ve kurtarıcı olduğundan söz edilmekte ve tarikatlar hakkında bilgiler verilmektedir. Bunu şair şu dizelerle ifade etmektedir: "Şerī' at èli birle bol hem sebk / Şerí atnı bil 'ālem içre çerāğ’. Garîbî, eserinin bu kısmında tarikatların şeriatsız olamayacağından bahsederken Nakşibendîlik ve Kâdirîlik tarikatlarının isimlerini zikreder. Buna örnek verebileceğimiz

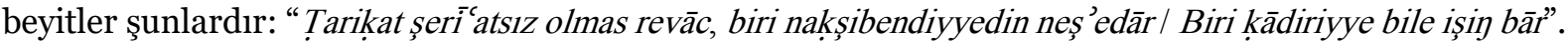
Bu kısım da 138. sayfanın üçüncü beytinde son bulmaktadır.

Garîbî, eserini kaleme alma sebebini yüz otuz dokuzuncu sayfanın yedi ve sekizinci beyitlerinde bulunan

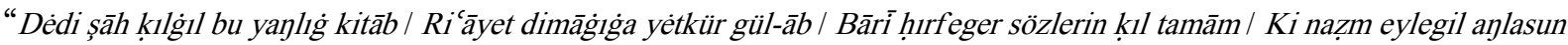

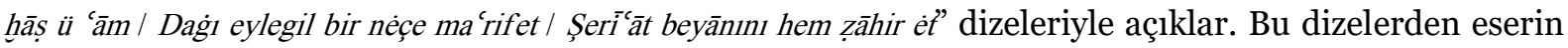
Zuhuridin Hakimbeg6'in emriyle meslek kollarının tanıtılması, şeriatın, dinî ve ahlakî ögelerin anlatılması için kaleme alındığı anlaşılmaktadır (http://teis.yesevi.edu.tr/madde-detay/garibi-turdinazim). Eserin yüz kırkıncı sayfasının altıncı beytinde kitabın adı geçmektedir: "cihān içre bolġaç kițāb-ı 'acīb/ ala ism boldı kitāb-1 garīib'.

Şairin hataları için dönemin okuyucularından yani kendi deyimiyle zaman ehlinden af dilediği, bu hatalarının okuyucu tarafından hoşgörülmesini istediği bölüm, eserin yüz kırk birinci sayfasındaki

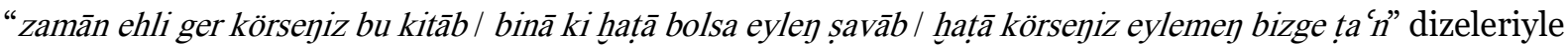
başlamaktadır.

Eserin yüz kırkinci sayfasında ise şair, eserin basıldığı matbaanın sahibi olduğu anlaşılan, "Yohannes Bey”in (Johannes Avetaranian'ın) sözlerine yer vermektedir. Şair bu kısma giriş yaparken kitabının basılıp halk arasında yayılmasını sağlayan Johannes Avetaranian'ın hem bu konuda hem de Kaşgar halkına muhabbetini göstermek için birkaç cümle söyleyeceğini şöyle açıklar: "uşbu kitābnıı basılıp ḩalk ara neşr ḳılınmaḳı barasıda söz dèmek ve basturguçı Yoḥannes Bey öz muhabbetni Kaşǵar ehlig̉a körgüzmek 
beyānıda". Bu kısım bittikten sonra yüz kırk üçüncü sayfada, "Kaşgarnı̣’'Iydgāhı" notuyla aşağıdaki fotoğraf yer almaktadır:

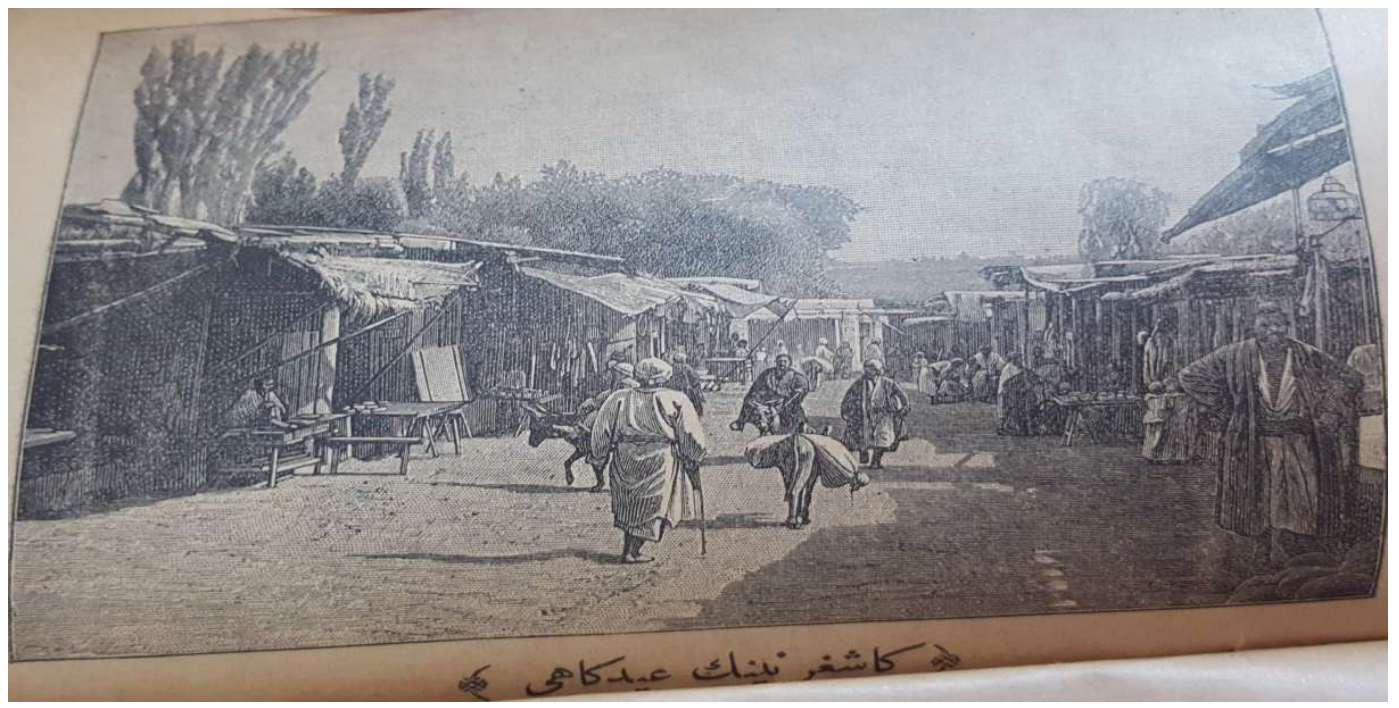

Resim 1: "Kaşġar’nın Iydgāhı"

Yüz kırk dört ve yüz kırk beşinci sayfalarda ise eserde basım sırasında yapılan hataları gösteren bir "hatāașavāb” cetveline yer verilmiştir. Bu cetvel hataların hangi sayfada ve hangi satırda olduğunu; sözcüklerin yanlış ve doğru yazımlarını açıkça gösterir.

\section{1 Kitâb-ı Garîbî'nin dil ve yazım özellikleri}

Türkologların, Türk dilinin tarihî devirlerinin adlandırılışı üzerine farklı görüş ve tasnifleri bulunmaktadır. Aynı durum Doğu Türkistan ve Orta Asya'da yaşayan Türklerin dillerinin adlandırılması hususunda da yaşanmaktadır. Bu adlandırmada öne çıan isimlerden biri şüphesiz Çağatay Türkçesiyken diğeri de Uygur Türkçesidir. Bu konuda araştırmacıların farklı görüş ve iddiaları bulunmaktadır. Saadet Çağatay 1921 yılında ilk defa Uygur adını kabul eden Doğu Türkistan'daki Türklerin kullandığı dil için "Yeni Uygur Türkçesi, bugünün Doğu Türkistan'ın dilidir." cümlesini kullanır (Çağatay, 1972: 52). Rıdvan Öztürk, "Yeni Uygur Türkçesi Grameri” adlı kitabında Uygur Türklerinin 1930'lu yıllara kadar Çağatay Türkçesini kullandıklarını ifade eder (Öztürk, 1994: 1). Sultan Mahmud Kaşgarlı ise “Çağdaş Uygur Türklerinin Modern Edebiyatı” adlı eserinde Uygur Türkçesinin Hakaniye Şivesi içinde şekillendiğini ve geliştiğini söylemekte ve Uygur Edebiyatının Çağatay Edebiyatı adı altında 13 ve 20. yüzyılları arasında yaşadığını ifade etmektedir (Kaşgarlı, 1998: 43-44).

Eckmann ise "Çağatay Dili Hakkında Notlar" makalesinde Çağatay Türkçesi tanımını yaparken 15-20. yy aralığını vererek bu dilin Orta Asya Türk devletlerinin, Avrupa Rusya'sındaki Oğuz Türkleri dışındaki Müslüman Türklerin dili olduğunu ve hatta Türkistan'da konuşulan dilin de ağızların etkisinde kalmış Çağatay Türkçesi olduğunu ifade eder. Yine aynı makalede Türkologların Türk dilleri ve Çağatay Türkçesi için yaptıkları farklı tasniflerine yer verdikten sonra Çağatay Türkçesini şu dönemlere ayırır (Eckmann, 1958: 115):

1. İlk Çağatayca veya Nevai'den Önceki Çağatayca Devri (15. Asır başlarından takriben Nevai'nin ilk eserini verdiği 1465 senesine kadar).

2. Klasik Çăgatayca Devri (1465-16. Asrın ortaları). 
3. Klasik Devirden Sonraki Çağatayca Devri (17. Asrın sonuna kadar).

4. Son Çă̆atayca Devri (18-19. Asırlar).

Eserin müellifi Turdî Nâzım'ın Kaşgar'da doğup büyüdüğü bilinmektedir. "Kitâb-ı Garîbî”nin H. 1257 (M. 1841-1842) kaleme alındığı ve H. 1320'de (M. 1902-1903) basıldığı göz önüne alındığında Eckmann'ın tasnifine göre eserin Çağatay Türkçesinin Klasik Sonrası devrine ait olduğu söylenebilir. Eckmann, Klasik Sonrası Devir için 1600-1921 yılları aralığını verir. Bu sebeple eserdeki yazım ve ses özellikleri değerlendirilirken ağırlıklı olarak Çağatay Türkçesi ve yer yer de Yeni Uygur Türkçesi yazım ve ses özellikleri esas alınacaktır.

\subsubsection{Yazım özellikleri}

è ünlüsü Çağatay Türkçesindeki aslî 9. ünlüdür. Eserde de bu harf işlek olarak kullanılmıştır. Metinde "è" nin yazımı elif (I) ve ye (⿶) ile gösterilmiştir. Bazı sözcüklerin yazımında ise ikilik söz konusudur.

“è” nin yazımında kullanılan elif (') ve ye (ى) harfinin birlikte yazıldığı kelimelerden birkaçı şöyledir:

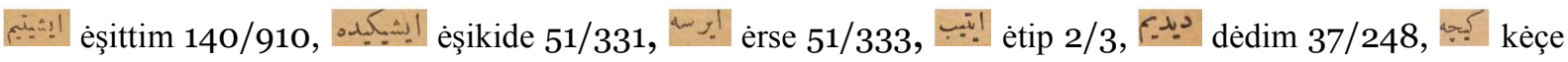
$13 / 82$.

Metinde geçen "nèdür" sözcüğündeki "e" harfi altı kere elif (I) ve ye (ى) "è" ile on iki kere de güzel he (॰) ile (e) yazılmıştır:

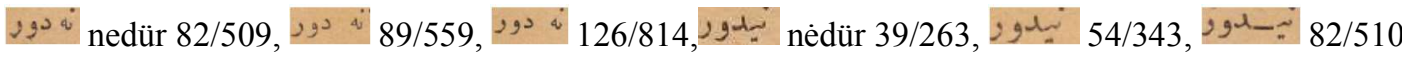

Çağatay Türkçesinde " $y$ " nin yazımı nun (ن) ve kef (ن) ile birleşik ņg (نك) şildedir. Eserde de "y" nin yazımı Çağatay Türkçesi dönemindeki yazma eserlerde olduğu gibidir. Eserde " $y$ ” nin yazımına örnek sözcüklerden bazıları şunlardır:

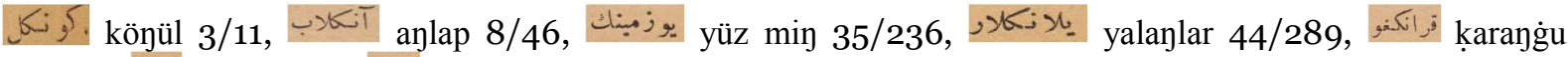
53/339, Kim sana 14/94, s si tanr1 83/515.

Kitâb-ı Garîbî'de "p" harfinin yazımında "be" (ب) ve "pe" (ب), harfleri dışında "fe" (ف) harfi de kullanılmaktadır. Örneğin, metinde yirmi kere geçen kop- "kalk-" fiili dört kere pe (ب) ile on altı kere ise fe (ف) ile yazılmıştır:

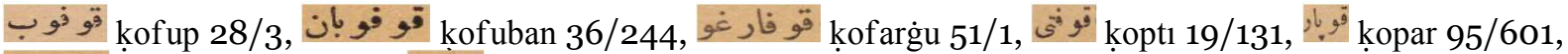

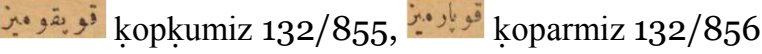

Metinde geçen tap- "bul-" fiilinin de üç farklı yazımını görmek mümkündür. Bu fiil on sekiz kere fe (ف) ile, dokuz kere pe (ب) ile, iki kere de be (ب) ile yazılmıştır. Bu farklı yazılışlara birkaç örnek aşağıdadır:

بأب tapar 36/241,

“İpek” sözcüğünün yazımında da ikilik olduğu görülmektedir:

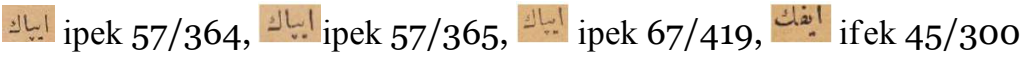

Bazı Türkçe sözcüklerin yazımındaki bu kararsızlık alıntı sözcüklerde de görülür: 
Farsçada "Meydana çıkmış, açığa vurulmuş, duyulmuş" anlamına gelen "faş" sözcü̆ğu metinde bir kere fe (ف) , üç kere de pe (ب) ile yazılmıştır:

pāş 4/15, ف̂̀ fāş 88/551

Eserde “toprak” sözcüğü üç kere geçmiş, üçünde de “tofraḳ” şeklinde yazılmıştır:

تض

Yine topuk, yapıştırmak, piste (Far. fıstık) ve pul sözcükleri istisnasız olarak fe (ف) ile yazılmıştır:

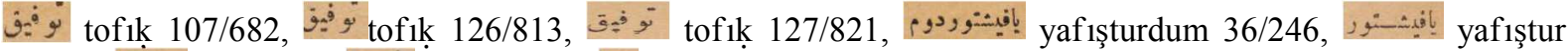
$87 / 539,4^{*}$ fiste 55/2,

Metinde geçen "gece” ve “çap-”sözcüklerinin hem cim (ج) ile hem de çim (æ) ile yazımı mevcuttur:

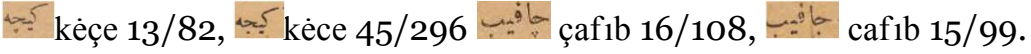

\section{Ses özellikleri}

Oğuzca bir unsur olan bol->ol- değişmesi eserde dikkati çeken özelliklerdendir. Ancak bu fiil eserde iki farklı şekilde kullanılmıştır. Eserde fiilin bol- şekline de ol- şekline de rastlanmıştır:

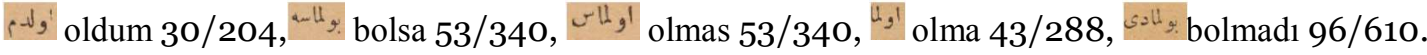

Doğu Türkçesinde görülen ünsüz ikizleşmesi Kitâb-ı Garîbî’de de görülmektedir:

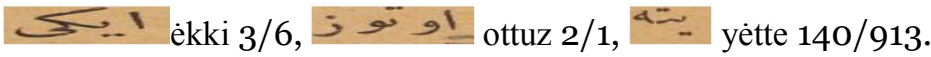

J. Eckmann Eski Türkçedeki söz içi ve söz sonundaki d sesinin Çağatay Türkçesinde y'ye dönüştüğünü ifade eder (Eckmann, 2017: 42). Bu özellik metinde de görülmektedir:

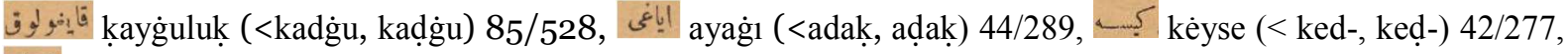
vile, koymas (< kod-, kod-) 16/108.

\section{Sonuç}

Bu makalede Yeni Uygur Edebiyatının son dönem Divan şairlerinden Kaşgarlı Nâzım Turdî (Garîbî)'ye ait adı çeşitli kaynaklarda Kitâb-ı Garîbî ve Divân-ı Garîbî olarak geçen "Ottuz Ėkki Eșnāfnın Birbiri İle Gep Talaşkanı” adlı eser muhteva, bazı dil, yazım ve ses özellikleri bakımından tanıtılmıştır. Eser 19. yy'da kaleme alınmış, 20. yy'ın başında ise Arap harfleriyle basılmıştır. Kaşgar'da kaleme alınan eser Bulgaristan'ın Şumnu şehrinde basılmıştır. İncelediğimiz ve tanıttığımız eser matbu olup eserin yazma nüshası hakkında bilgi bulunmamaktadır.

Eser, döneminin meslek kolları ve esnafların uyması gereken dinî-ahlakî kurallardan bahsettiği için dönemin sosyo-kültürel yapısı hakkında da önemli bilgiler barındırmaktadır. Bu sebepten eserin döneminde kılavuz bir kitap olduğu söylenebilir. Eserin dili sade ve üslubu ise süsten uzaktır. 
Eserin müellifi Yeni Uygur Edebiyatının temsilcilerinden olsa da eser ağırlıklı olarak Çağatay Türkçesinin son dönem özelliklerini barındırmaktadır. Bu sebeple eser incelenirken hem Yeni Uygurca hem de Çağatay Türkçesinin ses ve şekil bilgisinden yararlanılmıştır. Eserle ilgili daha geniş dil ve yazım incelemesi tarafımızdan hazırlanmakta olan yüksek lisans tezinde yer alacaktır. Kitâb-ı Garîbî̀nin tanıtılması 19. yy'da Orta Asya ve Doğu Türkistan'daki Türkler ve dönemin dil ve edebiyatı hakkında bilgi edinmek açısından önem arz etmektedir.

\section{Kaynakça}

Coşkun, M.V. (2017), Özbek Türkçesi Grameri, Ankara: TDK.

Çağatay, S. (1972), Türk Lehçeleri Örnekleri II, Ankara: Ankara Üniversitesi Basımevi.

Doğan, L. (2016), Uygur Türkçesi Grameri, İstanbul: Paradigma Akademi.

Eckmann, J. (2017), Çağatayca El Kitabı.( çev. G. Karaağaç). Ankara: TDK.

Eckmann, J. (1958), Çağatay Dili Hakkında Notlar. Türk Dili Araştırmaları Yillı̆̆ı-Belleten, C. 6, 115126.

Gönel Sönmez, T. (2017). [Adem Öger \& Recep Tek (Ed.), Risāle-i Mūze-Dūzluk (Ayakkabıcılık Risalesi), Yay. Haz: Ahmet Turan Türk, Ekber Enveri, Zulhayat Ötkür, Kamile Serbest, Ankara: Gazi Kitabevi, 2017, 289 s. Künyeli kitabın değerlendirmesi]. Uluslararası Uygur Araştırmaları Dergisi, 2017/10,161-162.

Kasapoğlu Çengel, H. (2013), Çağdaş Uygur Edebiyatı, Y. Akpınar. \& F. Ağca, Çağdaş Türk Edebiyatları II, (s. 140-170), Eskişehir: Anadolu Üniversitesi Web-Ofset.

Kaşgarlı, S. M. (1998), Çağdaş Uygur Türkleri’nin Edebiyatı, Ankara: Neyir Matbaacılık.

Öger, Adem. \& Yllmaz, Kadri. (2011), Uygur Sahasinda Yetişmiş Bir Divan Şairi: Abdurehim Nizarî. Nevşehir Üniversitesi Sosyal Bilimler Enstitüsü Dergisi, 1 (2011), 36-50.

Öztürk, R. (1994), Yeni Uygur Türkçesi Grameri, Ankara: TDK.

Öztürk, R. (1997), Uygur ve Özbek Türkçelerinde Fül, Ankara: TDK.

Shaw, R. B. (2014), Kaşgar ve Yarkend Ağzı Sözlüğü, (Çev. F. Yıldırım). Ankara: TDK.

Ünlü, S. (2013), Çağatay Türkçesi Sözlüğ̈̈, Konya: Eğitim Yayınevi.

\section{Çevrimiçi kaynaklar}

"GARÎB̂̂, Turdî Nâzım”, Türk Edebiyatı İsimler Sözlüğü, 04 Nisan, 2020'de erişildi, http://teis.yesevi.edu.tr/madde-detay/garibi-turdi-nazim . 
502 / RumeliDE Journal of Language and Literature Studies 2020.19 (June)

The work of poet Turdî Nâzım Garîbî's Kitâb-ı Garîbî / E. Güneş Asil, S. Murad (pp. 494-503)

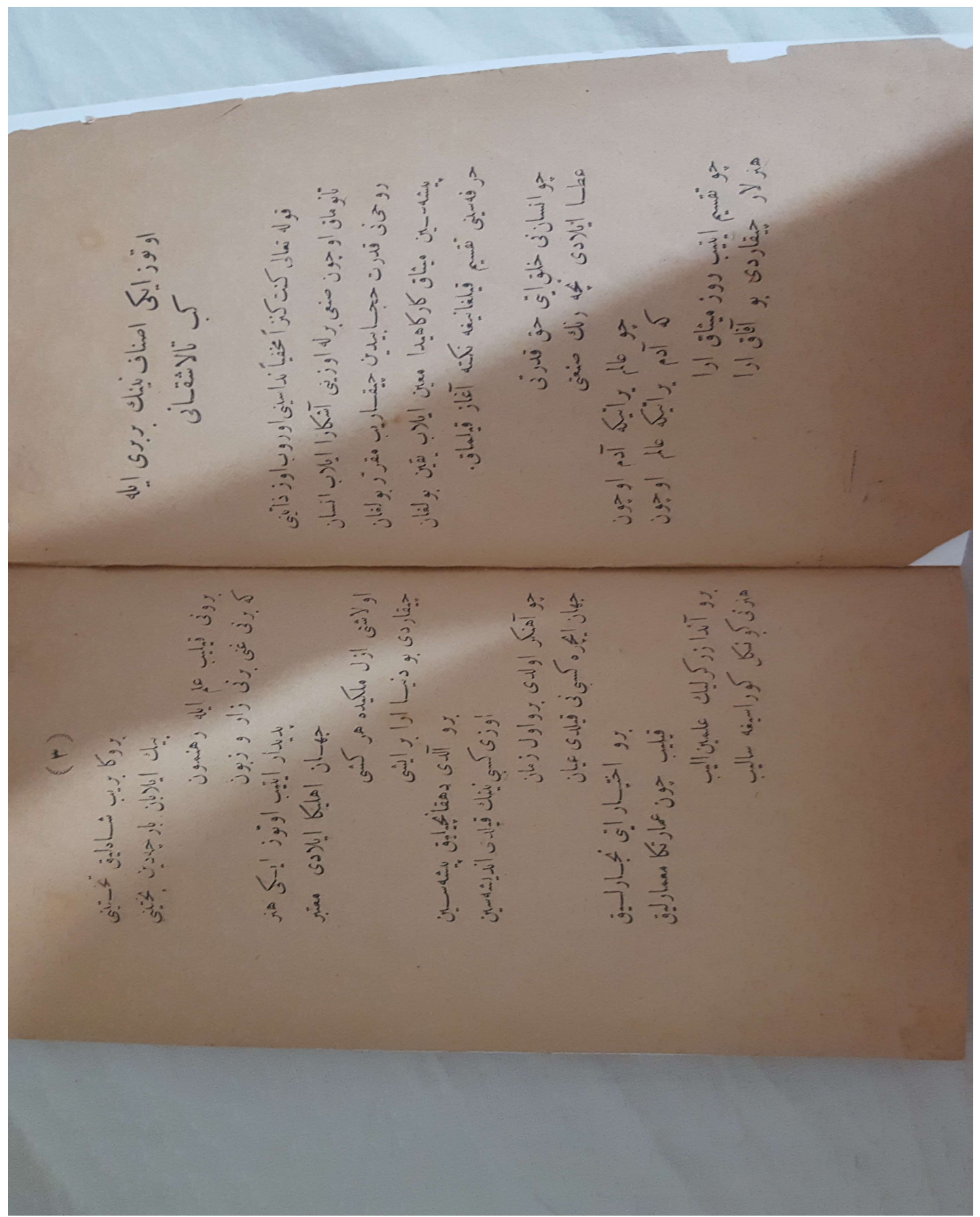

Resim 2

Adres 


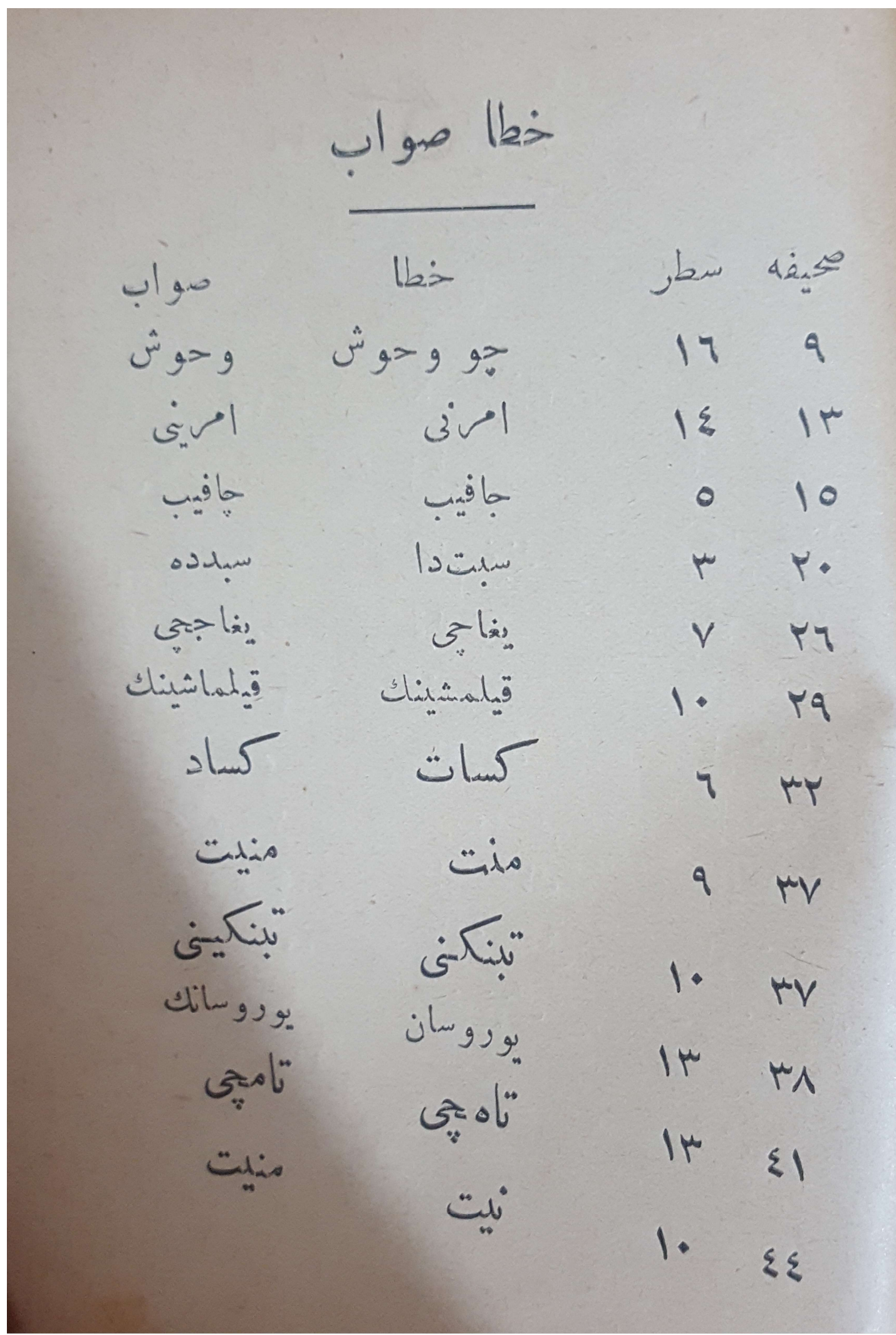

$\operatorname{Resim} 3$

Adres 